\title{
NEW MINERALS OF THE GROUP OF IRON ANTIMONIDES AND ARSENIDES FROM SEINÄJOKI DEPOSIT, FINLAND
}

\author{
N. N. MOZGOVA, Yu. S. BORODAEV, N. A. OZEROVA and \\ V. PÄÄKKÖNEN
}

\begin{abstract}
MOZGOVA, N. N., BORODAEV, YU. S., OZEROVA, N. A. and PÄKKKÖNEN, V. 1977: New minerals of the group of iron antimonides and arsenides from Seinäjoki deposits, Finland. Bull. Geol. Soc. Finland 49: 47-52.

This article gives pertinent data of two minerals, previously unknown in nature, seinäjokite $-\left(\mathrm{Fe}_{0.8} \mathrm{Ni}_{0.2}\right)\left(\mathrm{Sb}_{1.7} \mathrm{As}_{0.3}\right)_{2}$ and the antimony westerveldite $-\mathrm{Fe}\left(\mathrm{As}_{0.95} \mathrm{Sb}_{0.05}\right)$; also described is the mineral association in which they occur.

N. N. Mozgova, Yu. S. Borodaev and N. A. Ozerova, Institute of Geology of Ore Deposits, Petrography, Mineralogy and Geochemistry, USSR Academy of Sciences, Staromonetny 35, Moscow, USSR.

V. Pääkkönen, Riippakoivuntie 19, SF-02130 Espoo 13, Finland.
\end{abstract}

Two minerals unknown to date were found in the Seinäjoki deposit in a specimen of native antimony*).

In chemical composition and structure one of these new minerals is close to the antimony analog of löllingite and to the phase $\mathrm{FeSb}_{2}$ in alloy. This is the first time that such a compound has been found in nature and therefore it is described as a new mineral species. The name, taken from the Seinäjoki deposit, was affirmed by the Comission on New Minerals and Mineral Names of the

*) More data on these minerals can be found in the paper Mozgova et al., 1976. The geology and mineralogy of the deposit were described in the monography by V. Pääkkönen (1966).
International Mineralogical Association on 28-II-1976.

Seinäjokite occurs as irregular grains, more rarely idiomorphic crystals with rhombic sections, from 0.2 to $0.3 \mathrm{~mm}$ in size (Fig. 1). The chemical composition was determined by JXA-5 electron microprobe (Table 1). The abundances of the elements vary only slight$\mathrm{ly}$; the variations of $\mathrm{Fe}$ and $\mathrm{Ni}$, as well as $\mathrm{Sb}$ and As exhibit reverse relation. These facts are evidence of the variation in composition of the mineral and the isomorphism between these elements. The average formula is $\left(\mathrm{Fe}_{0.78} \mathrm{Ni}_{0.19} \mathrm{Co}_{0.03}\right)_{1.00} \cdot \mathrm{Sb}_{1.71} \mathrm{As}_{0.26}$ $\left.\mathrm{Fe}_{0.03}\right)_{2.00}$ or in generalized form $-\left(\mathrm{Fe}_{0.3}\right.$ $\left.\mathrm{Ni}_{0.2}\right) \cdot\left(\mathrm{Sb}_{1.7} \mathrm{As}_{0.3}\right)_{2}$. The X-ray powder pattern of seinäjokite (Table 2) is closed to that of the 


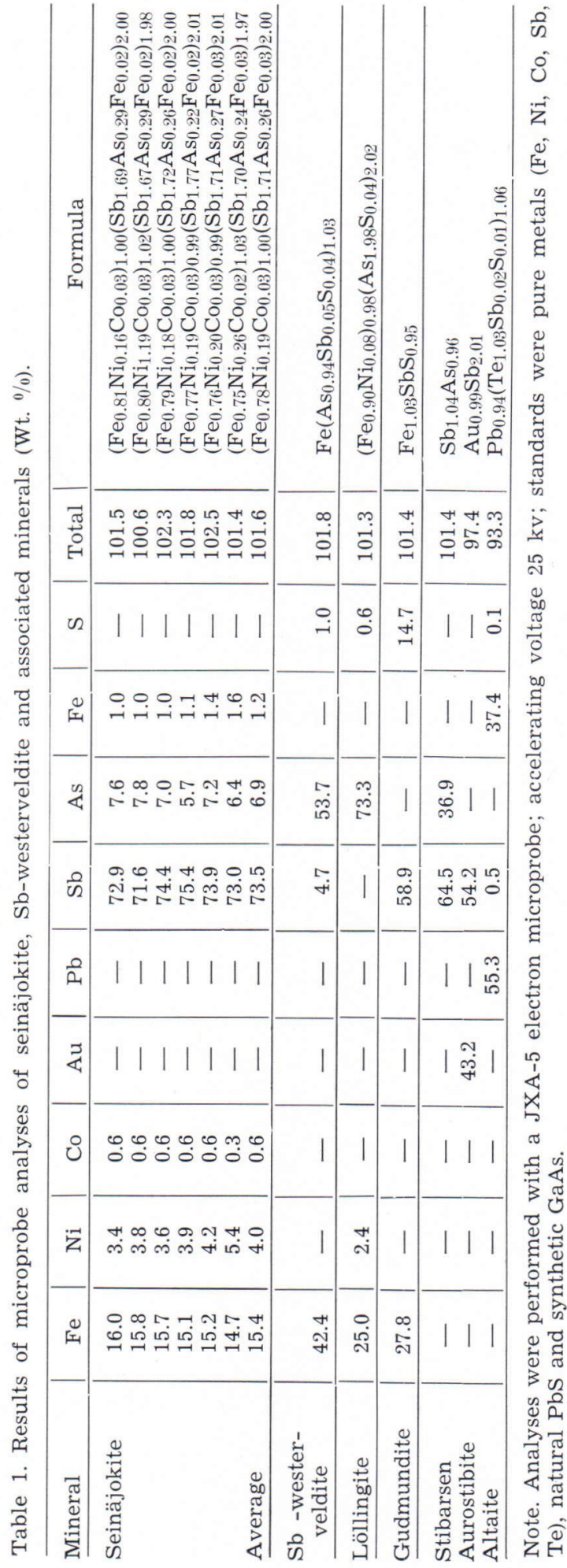

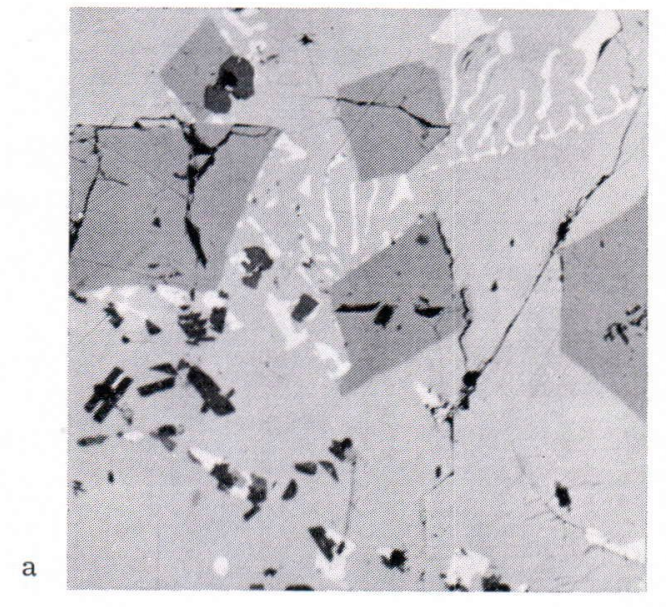

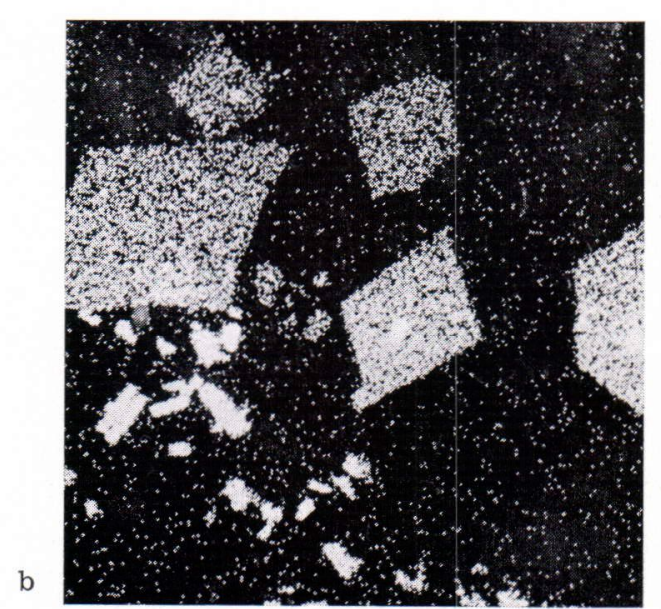

Fig. 1. Crystals of seinäjokite (grey) and $\mathrm{Sb}-$ westerveldite (black) in native antimony (light grey). Altaite (white) forms graphic intergrowths with antimony. Magn. 170x. a- back-scattered electron image; $\mathrm{b}-\mathrm{FeK}_{\alpha_{1}} \mathrm{X}$-ray image.

synthetic phase $\mathrm{FeSb}_{2}$. The unit cell of the mineral may be orthorhombic or pseudoorthorhombic. The calculated density is 7.938 (with $\mathrm{a}_{0}=3.189, \mathrm{~b}_{0}=5.819, \mathrm{c}_{0}=6.520 \AA$ and $\mathrm{Z}=2$ ).

In reflected light, seinäjokite is grey with a pinkish tint. Reflectance is high, and dispersion of reflectivity is insignificant (Table 3). Bireflectance is unnoticeable in air, whereas anisotropy is distinct with a coloured effect - from brownish to bluish. It polishes well. 
Table 2. X-ray diffraction pattern of seinäjokite $\left(\mathrm{a}_{0}=3.19 \pm 0.01 \AA, \mathrm{b}_{0}=5.81 \pm 0.01 \AA, \mathrm{c}_{0}=6.49\right.$ $\pm 0.015 \AA)$

\begin{tabular}{llrr}
\hline I & d meas. & hkl & d calc. \\
\hline 10 & 2.81 & $\left\{\begin{array}{l}012 \\
110\end{array}\right.$ \\
9 & 2.59 & 111 & 2.83 \\
0,5 & 2.12 & 112 & 2.57 \\
8 & 2.03 & $\{121$ & 2.12 \\
& & & 2.04 \\
1 & $1.818^{*}$ & $\{103$ & 2.03 \\
6 & 1.790 & $\{122$ & 1.791 \\
1 & 1.710 & 113 & 1.791 \\
2 & 1.626 & 004 & 1.711 \\
2 & 1.523 & 123 & 1.524 \\
1 & 1.407 & $\{041$ & 1.417 \\
3 & 1.212 & 212 & 1.390 \\
3 & 1.174 & 115 & 1.210 \\
1 & 1.153 & 232 & 1.177 \\
1 & 1.077 & 151 & 1.151 \\
1 & 1.053 & 301 & 1.047 \\
\hline
\end{tabular}

Note. RKD camera, D $=57.3 \mathrm{~mm}, \mathrm{CuK}_{\alpha}$ radiation, $40 \mathrm{kv}-5 \mathrm{ma}$. Absorption correction was not efectuated because of the small size of the rubber ball with the sample.

* - the line is not indicated.

Seinäjokite is less bright but with higher relief than native antimony. The microhardness is $330 \mathrm{~kg} / \mathrm{mm}^{2}$ (with the load of $30 \mathrm{~g}$ ). The impression is quadrate and slightly concave with cracks. The mineral is transparent in near infra-red light ( $\lambda$ - up to 1.2 micron).

It has been suggested that the name seinäjokite be used for natural solid solutions having orthorhombic symmetry and the composition $\mathrm{Fe}(\mathrm{As}, \mathrm{Sb})_{2}$ (when $\mathrm{Sb} \gg \mathrm{As}$ ).

The other mineral, $\mathrm{Fe}\left(\mathrm{As}_{0.95} \mathrm{Sb}_{0.5}\right)$, has likewise gone undetected in nature until now. In samples of chromite-niccolite ore from La Gallega (Spain), I.S. Den et al. (1972) recently discovered a new mineral, westerveldite ( $\mathrm{Fe}$, $\mathrm{Ni}, \mathrm{Co}) \mathrm{As}$, containing from 13.4 to $17.4 \% \mathrm{Ni}$. The authors proposed the name westerveldite for the orthorhombic FeAs - (Fe, Ni)As solid solution series. Later, westerveldite of a similar composition was found in an assemblage of disseminated arsenides in serpentinized

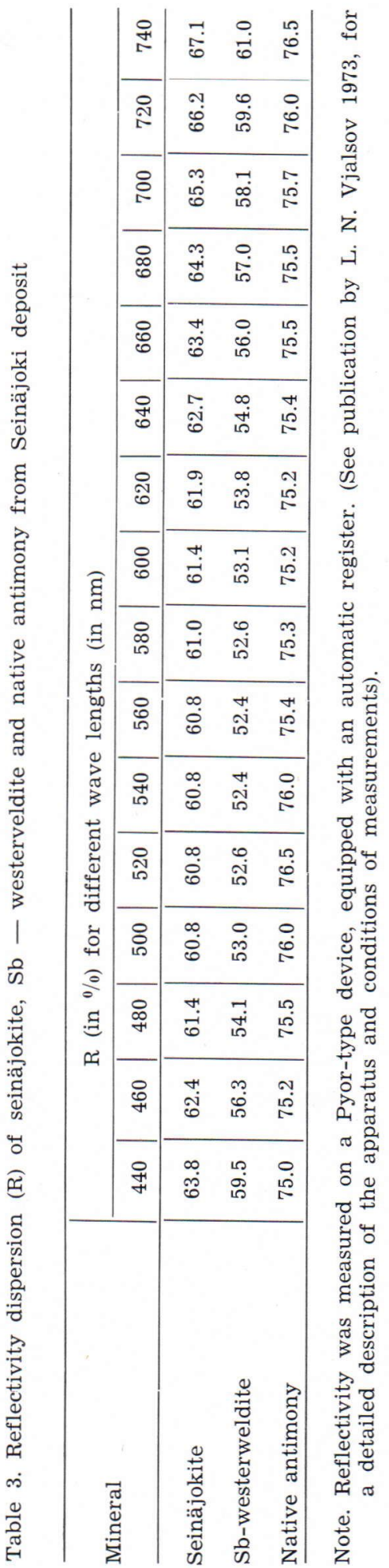



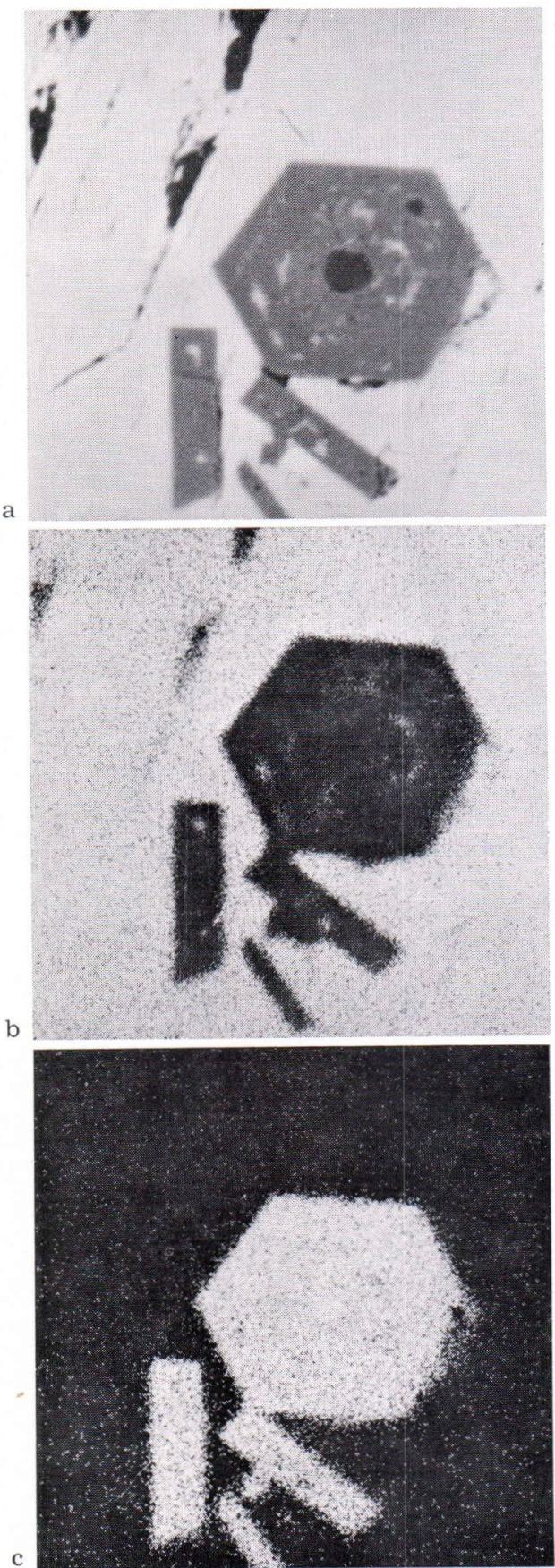

Fig. 2. Crystals of Sb-westerveldite in native antimony. Sb-westerveldite has inclusions of pyrrhotite (black) and antimony (white). Black spots in the field of native antimony are defects in polishing. Magn. $680 x$. a - back-scattered electron image; $\mathrm{b}-\mathrm{SbL}_{\alpha_{1}} \mathrm{X}$-ray image; $\mathrm{c}-\mathrm{FeK}_{\alpha_{1}}$ $\mathrm{X}$-ray image.

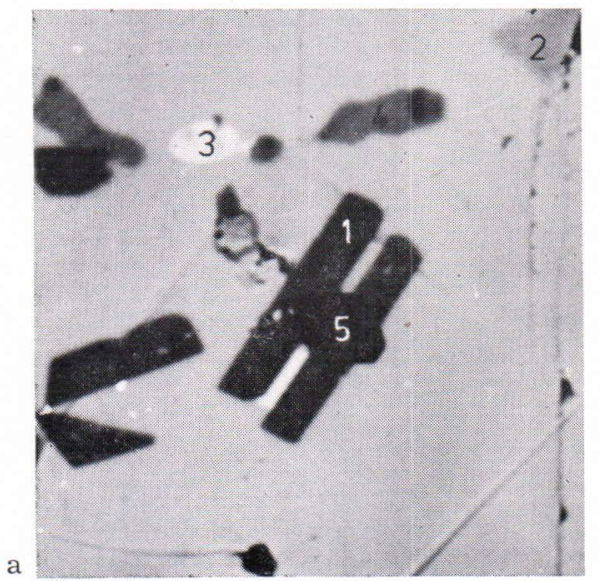

b
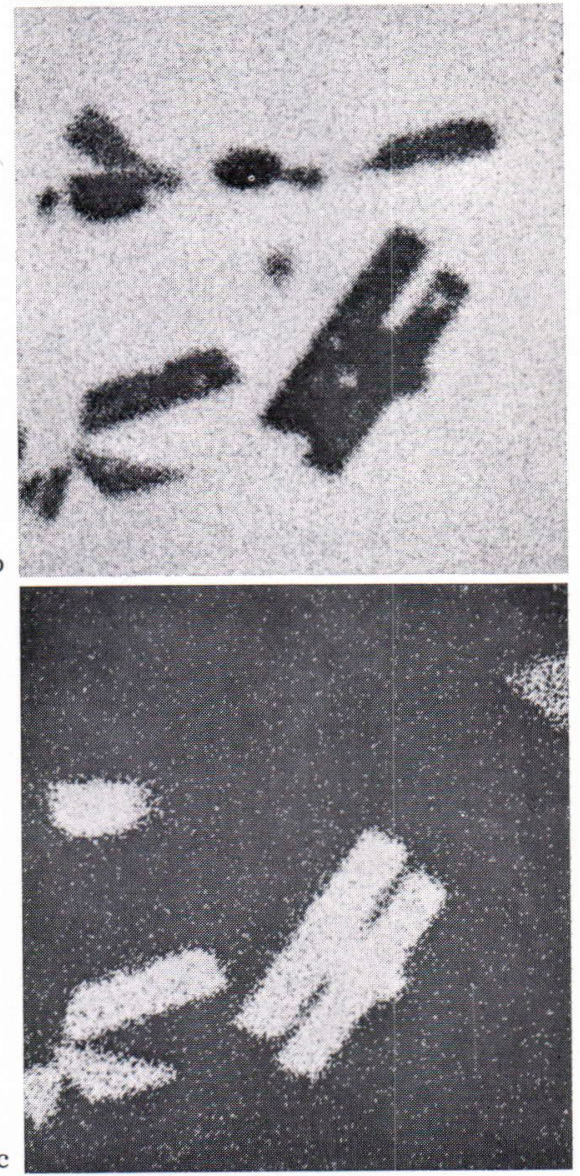

Fig. 3. Sb-westerveldite (1), seinäjokite (2) and tellurides in native antimony. 3-altaite; 4-nondetermined telluride; 5-pyrrhotite. Magn. 700x. $\mathrm{a}$ - back-scattered electron image; $\mathrm{b}-\mathrm{SbL}_{\mathrm{a}_{1}}$ $\mathrm{X}$-ray image; c-FeK ${ }_{\alpha_{1}} \mathrm{X}$-ray image. 
peridotite near Birchtree mine in Canada (Sizgoric and Duesing, 1973).

The $\mathrm{Fe}$-arsenide that we discovered at Seinäjoki does not contain $\mathrm{Ni}$ and is the first find of a wholly nickel-free member of this series. The mineral contains about $5 \%$ $\mathrm{Sb}$ (Table 1) and we propose that this mineral be considered as an antimony variety of westerveldite ( $\mathrm{Sb}$-westerveldite). Sb-westerveldite occurs as isometric grains, up to 0.1 $\mathrm{mm}$ in diameter, with characteristic hexagonal, rectangular and trapezoidal sections (Fig. 2).

The composition of the mineral corresponds to the formula $\mathrm{Fe}\left(\mathrm{As}_{0.94} \mathrm{Sb}_{0.05} \mathrm{~S}_{0.4}\right)_{1.03}$ (Table 1). Its $\mathrm{d}$-values and line intensities (the powder pattern was obtained only for the mixture of this mineral and native antimony - see Table 4) are closer to those of the synthetic compound FeAs than of the westerveldite from La Gallega. The calculated density (taking into account the parameters of FeAs) is 7.907. In reflected light it is pinkish grey, darker than native antimony and shows a higher relief than the native mineral. In comparison with seinäjokite it is pinkish brown, and exhibits less reflectance and a higher relief. Sb-westerveldite contains inclusions of pyrrhotite (often in the centre of grains) and native antimony (Fig. 2 and 3 ).

Both minerals replace native antimony and associate with altaite and other non-determined tellurides (Fig. 3). The latter minerals were discovered in ores of the Seinäjoki deposit for the first time. Near this association native antimony contains 0.3 to $0.4 \%$ As, but at some distance the content of As increases to $7 \%$. In other parts of the same specimen, stibarsen (SbAs) and aurostibite $\left(\mathrm{AuSb}_{2}\right)$ were found for the first time in the Seinäjoki deposit. Stibarsen forms chains of small crystals and irregular grains. In reflected light it is pinkish white, distinguished from native antimony with difficulty and
Table 4. X-ray diffraction pattern of Sb-westerveldite.

\begin{tabular}{|c|c|c|c|}
\hline \multicolumn{2}{|c|}{$\begin{array}{l}\text { Mixture of Sb-wester- } \\
\text { veldite and native } \\
\text { antimony, Seinäjoki } \\
\text { deposit }\end{array}$} & \multicolumn{2}{|c|}{$\begin{array}{l}\text { Sb-westerveldite, } \\
\text { Seinäjoki deposit; } \\
\text { (corrected for } \\
\text { native antimony) }\end{array}$} \\
\hline I & d $\AA$ meas. & hkl & $\mathrm{d} \AA$ correct. \\
\hline 10 & 3.13 & & \\
\hline 0.5 & $2.96 *)$ & 110 & 2.92 \\
\hline 2 & $2.66 *)$ & 021 & 2.64 \\
\hline 6 & $2.61 *)$ & 111 & 2.59 \\
\hline 2 & $2.50 *)$ & 012 & 2.48 \\
\hline 6 & 2.26 & & \\
\hline 6 & 2.16 & & \\
\hline 3 & $2.10 *)$ & 102 & 2.08 \\
\hline $4 w$ & $2.02 *)$ & 022 & 2.01 \\
\hline 1 & 1.939 & & \\
\hline 1 & 1.891 & & \\
\hline 4 & 1.775 & & \\
\hline 4 & $1.739 *)$ & 013 & 1.736 \\
\hline 1 & $1.704 *)$ & 200 & 1.700 \\
\hline 0.5 & $1.633 *)$ & 032 & 1.630 \\
\hline 4 & $1.559 * *)$ & & \\
\hline 2 & $1.422 * *)$ & 221 & 1.422 \\
\hline 4 & 1.373 & & \\
\hline 1 & $1.265 * *)$ & 231 & 1.265 \\
\hline 0.5 & 1.241 & & \\
\hline 0.5 & $1.217 * *)$ & 114 & 1.217 \\
\hline 0.5 & $1.127 * *)$ & 223 & 1.127 \\
\hline 0,5 & $1.076 * *)$ & 311 & 1.076 \\
\hline
\end{tabular}

Note. RKD camera, $\mathrm{D}=57,3 \mathrm{~mm}, \mathrm{CuK} \alpha$ radiation (Ni filter), 40kv-5ma. *) — the lines of westerveldite; ${ }^{* *}$ ) — the lines common for westerveldite and native antimony.

situated on grain boundaries of this mineral. Aurostibite was encountered in antimony at the contact with quartz as a single isometric crystal, $0.15 \mathrm{~mm}$ in diameter. It shows less reflectance than antimony and has a pinkish yellow tint.

The established mineral association arsenides, antimonides tellurides - is characterized by a distinct deficience in sulphide sulphur. Hence, solutions from which early native antimony and the above-mentioned minerals were formed contained only insignificant amounts of dissociated $\mathrm{H}_{2} \mathrm{~S}$. The role of the latter becomes marked only during the final stages of deposition when antimonite is formed. The antimonides and arsenides described evidently obtained arsenic and antimony from native antimony. 


\section{References}

Mozgova, N. N., Borodaev, Yu. S., Ozerova, N. A., Pääkkönen, V., Sveschnikova, O. L., Balitskii, V. S. and Dorogovin, B. A. (1976) Seinäjokite $\left(\mathrm{Fe}_{0.8} \mathrm{Ni}_{0.2}\right)\left(\mathrm{Sb}_{1.7} \mathrm{As}_{0.3}\right)_{2}$ i surmjanistii vesterveldite $\mathrm{Fe}\left(\mathrm{As}_{0.95} \mathrm{Sb}_{0.05}\right)$ iz Seinäjoki (Finlandija). Zapiski Vsesojusnogo Mineralog. Obschestwa, $\mathrm{N} 6$ (in Russian).

Cen, I. S., Burke E. A. Y., Kift, C. and Westerhof, A. B. (1972) Westerveldite (Fe, Ni, Co) As, a new mineral from La Gallega, Spain. Am. Miner. 57 (3-4).
Sizgoric, M. B. and Duesing, C. M. (1973) Westerveldite, a Canadian occurrence. Canad. Miner. 12, p. 2.

Pääkkönen, V. (1966) On the geology and mineralogy of the occurrence of native antimony at Seinäjoki, Finland. Bull. Comm. Géol. Finlande 225 .

Vjalsov, L. N. (1973) Reflection spectra of ore minerals. IGEM (in Russian).

Manuscript received, September 28, 1976. 